\title{
Green Bonds like the Incentive Instrument for Cleaner Production at the Government and Corporate Levels: Experience from EU to Ukraine
}

- Olena CHYGRYNSumy State University, Ukraine

- Tetyana PIMONENKOSumy State University, Ukraine

- Oleksii LUYLYOVSumy State University, Ukraine

- Alina GONCHAROVASumy State University, Ukraine

DOI: https://doi.org/10.14505//jemt.v9.7(31).09

\section{Abstract}

The paper deals with analysis of the main features and perspectives of green bonds development. Under the investigation the European Union experience of developing and functioning the green bonds market were analysed by the authors. The authors systematised the main approaches to define green bonds. Thus, the green bonds were defined as the debt investment in which an investor loans money which borrows the funds for a defined period at a variable or fixed interest rate with purpose to raise money and finance the variety of green projects and activities. In this direction, green projects mean the all activities which connected with resources saving and environmental protection activities. According to this result, the main features, parameters and principles of green bonds were indicated by the authors. Besides, based on the European Union experience the authors allocated the main prerequisites of developing the green bonds market in Ukraine. Moreover, the authors allocated the main players at the green bonds market. According to the European Union experience and Ukraine conditions, the attractive directions of green bonds market for investors were identified by the authors. With this purpose the authors tried to consolidate the main advantages and disadvantages of green bonds for investors. According to the results, in conclusion, the authors allocated the possible economic, social, political and environmental benefits of green bonds market for issuers with purpose to attract their attention and to develop the green bonds market in Ukraine.

\section{References}

[1] Abaas, M. S. M., Chygryn, O., Kubatko, O., and Pimonenko, T. 2018. Social and economic drivers of national economic development: The case of OPEC countries. Problems and Perspectives in Management, 16(4): $155-168$. doi:10.21511/ppm.16(4).2018.14

[2] Aliyas, I. M., Ismail, E. Y., and Alhadeedy, M. A. H. 2018. Evaluation of Applications of Sustainable Agricultural Development in Iraq. SocioEconomic Challenges, 2(2): 75-80. DOI: 10.21272/sec.2(2).75-80.2018

[3] Barclays MSCI ESG. Fixed Income Indices a New Market Standard for Environmental, Social, and Governance Investing. (2013), Available at:

https://www.msci.com/documents/10199/248121/Barclays_MSCI_ESG_Fixed_Income_Indices_-

FINAL.pdf/e70bf030-1373-40ad-a725-05bf9005fea8?version $=1.0$

[4] Bond Definition. Investopedia. Available at: http://www.investopedia.com/terms/b/bond.asp\#ixzz4briZMNYp

[5] Bonds and Climate Change the State of the Market in 2016. Climate Bonds Initiative, Available at:

https://www.climatebonds.net/resources/publications

[6] Cebula, J., and Pimonenko, T. 2015. Comparison financing conditions of the development biogas sector in poland and ukraine. International Journal of Ecology and Development, 30(2): 20-30.

[7] Celik, S., Aktan, B., Tvaronaviciene, M., and Bengitoz, P. 2017. Linkage between company scores and stock returns. Journal of International Studies, 10(4): 219-232. doi:10.14254/2071-8330.2017/10-4/17

[8] Chigrin, O., and Pimonenko, T. 2014. The Ways of Corporate Sector Firms Financing for Sustainability of Performance. International Journal of Ecology \& Development ${ }^{\mathrm{TM}}$ 29.3: 1-13.

[9] Chirichenko, Y., and Fisunenko, N. 2018. Marketing determinants of the development of the investment market: innovations in the assessment of demand and supply (case study for the construction industry). Marketing and Management of Innovations, (3): 81-94.

[10] Chygryn, O. 2016. The Mechanism of the Resource-Saving Activity at Joint Stock Companies: the Theory and Implementation Features. International Journal of Ecology \& Development ${ }^{\mathrm{TM}}$, 31.3: 42-59.

[11] Chygryn, O., Petrushenko, Yu., Vysochyna, A., and Vorontsova, A. 2018. Assessment of Fiscal Decentralization Influence on Social and Economic Development. Montenegrin Journal of Economics, 14(4): 69-84. Doi:

10.14254/1800-5845/2018.14-4.5

[12] Chygryn, O.Yu., and Krasniak, V.S. 2015. Theoretical and applied aspects of the development of environmental investment in Ukraine. Marketing and Management of Innovations, 3: 226-234.

[13] CO2 time series 1990-2015 per region/country. Available

at:http://edgar.jrc.ec.europa.eu/overview.php?v=CO2ts1990-2015\&sort=des9

[14] Craig A., Gulati, S., and McDonald, C. 2013. Green Bonds: Victory Bonds for the Environment Special Report TD Economics. Available at: http://www.td.com/document/PDF/economics/special/GreenBonds_Canada.pdf

[15] Dado, J., Prokopenko, O., and Pimonenko, T. 2017. Net zero house: EU experience in ukrainian conditions. International Journal of Ecological Economics and Statistics, 38(4): 46-57. 
[16] Dovhan, Z., Kravchuk, I., and Karas, P. 2017. The financial instruments market-an institutional approach. Financial Markets, Institutions and Risks. 1(1): 22-28. DOI: 10.21272/fmir.1(1).22-28.2017

[17] Explaining green bonds. Climate Bonds Initiative. Available at: https://www.climatebonds.net/market/explaininggreen-bonds

[18] Fernandes, A. J. L. 2018. Transnational banks' influence on the development of the economy and the financial sector of developing countries (on the example of Poland, Brazil, Turkey). Marketing and Management of Innovations, (3): 253-259.

[19] Flaherty, M., et al. 2016. Financing climate policies through climate bonds - A three stage model and empirics. Res. Int. Business Finance, 42: 468-479. http://dx.doi.org/10.1016/j.ribaf.2016.06.001

[20] Green Bond Principles. Voluntary Process Guidelines for Issuing Green Bonds. (2016). International Capital Market Association. Available at: https://www.icmagroup.org/Regulatory-Policy-and-Market-Practice/green-socialand-sustainability-bonds/green-bond-principles-gbp/

[21] Green Bond. Impact report. The World Bank, June 2016. Available at:

http://treasury.worldbank.org/cmd/pdf/WorldBankGreenBondlmpactReport.pdf

[22] Green bonds as a bridge to the SDGs. (2018). Available at:

https://www.climatebonds.net/files/files/CBl\%20Briefing\%20Green\%20Bonds\%20Bridge\%20to\%20SDGs\%281\%29.p df

[23] Green Bonds: Mobilising the Debt Capital Markets for a Low-Carbon Transition. (2015). OECD and Bloomberg Philanthropies. Available at: https://www.oecd.org/environment/cc/Green\%20bonds\%20PP\%20[f3]\%20[Ir].pdf

[24] Green Bonds. Financing a Sustainable Future. Available at: http://www.gogreenbonds.org/faqs/\#1

[25] Green Finance: Green Bond Directions. COP22. 2016. Climate Bonds Initiative. Available at: https://www.climatebonds.net/files/files/COP22_Directions_WEB.pdf

[26] Halim, E. H., Mustika, G., Sari, R. N., Anugerah, R., and Mohd-Sanusi, Z. 2017. Corporate governance practices and financial performance: The mediating effect of risk management committee at manufacturing firms. Journal of International Studies, 10(4): 272-289. doi:10.14254/2071-8330.2017/10-4/21

[27] ICMA 2015. Green Bond Principles: Voluntary Process Guidelines for Issuing Green Bond, March.

[28] IEA 2012. Energy Technology Perspectives, OECD/IEA Publishing, Paris.

[29] IEA 2014. World Energy Investment Outlook, OECD/IEA Publishing, Paris.

[30] IEA 2015. World Energy Outlook, November, OECD/IEA Publishing, Paris.

[31] Inderst, G. et al. 2012. "Defining and Measuring Green Investments: Implications for Institutional Investors' Asset Allocations", OECD Working Papers on Finance, Insurance and Private Pensions, No.24, OECD Publishing, Paris.

[32] India: New stock index to reflect environmental, social and corporate governance issues. Energy Asia, February 4, 2008. Available at: http://energyasia.com/public-stories/india-new-stock-index-to-reflect-environmental-social-andcorporate-governance-issues/

[33] Kennedy, C. and Corfee-Morlot, J. 2012. "Mobilising Investment in Low-carbon, Climate Resilient Infrastructure", OECD Environment Working Papers, No. 46, OECD Publishing, Paris

[34] Khan, K., Qingyang, W., and Khurshid, A. 2017. Causal Relationship between Monetary Policy and the Stock Market: a Bootstrap Rolling Window Approach. Financial Markets, Institutions and Risks, 1(4): 5-15.

10.21272/fmir.1(4).5-15.2017

[35] Kiss, L. B. 2018. The Examination of the Appearance of CSR in On-line Scientific Databases. Business Ethics and Leadership, 2(2): 56-65. DOI: 10.21272/bel.2(2).56-65.2018

[36] Kozmenko, S. M., Vasilyeva, T. A., and Leonov, S. V. 2011. Ukraine and Germany: Common tendecies of financial market development according to the bank-centered model. Corporate Ownership and Control, 9(1 C): 247273. doi:10.22495/cocv9i1c2art1

[37] Kubatko, O., and Kubatko, O. 2018. Economic estimations of air pollution health nexus. Environment, Development and Sustainability, 1-11. doi:10.1007/s10668-018-0252-6

[38] Leonov, S. V., Vasylieva, T. A., and Tsyganyuk, D. L. 2012. Formalization of functional limitations in functioning of co-investment funds basing on comparative analysis of financial markets within FM CEEC. Actual Problems of Economics, 134(8): 75-85.

[39] Leonov, S., Frolov, S., and Plastun, V. 2014. Potential of institutional investors and stock market development as an alternative to households' savings allocation in banks. Economic Annals-XXI, 11-12: 65-68.

[40] Lyulyov O., and Pimonenko, T. 2017. Lotka-Volterra model as an instrument of the investment and innovative processes stability analysis. Marketing and Management of Innovations, 1: 93-102.

[41] Lyulyov, O., Chortok, Y., Pimonenko, T., and Borovik, O. 2015. Ecological and economic evaluation of transport system functioning according to the territory sustainable development. International Journal of Ecology and

Development, 30(3): 1-10.

[42] Mačaitytè, I., and Virbašiūtè, G. 2018. Volkswagen Emission Scandal and Corporate Social Responsibility - A Case Study. Business Ethics and Leadership, 2(1): 6-13. 10.21272/bel.2(1).6-13.2018

[43] Melnyk, L., Sineviciene, L., Lyulyov, O., Pimonenko, T., and Dehtyarova, I. 2018. Fiscal decentralization and macroeconomic stability: The experience of Ukraine's economy. Problems and Perspectives in Management, 16(1): 105-114. doi:10.21511/ppm.16(1).2018.10

[44] Mikalauskiene, A., Narutaviciute-Cikanauske, R., Sarkiunaite, I., Streimikiene, D., and Zlateva, R. 2018. Social aspect of sustainable development: Issues of poverty and food shortage. Montenegrin Journal of Economics, 14(2): 59-78. doi:10.14254/1800-5845/2018.14-2.4

[45] Mohamad Taghvaee, V., Khodaparast Shirazi, J., Boutabba, M. A., and Seifi Aloo, A. 2017. Economic growth and renewable energy in Iran. Iranian Economic Review, 21(4): 789-808. doi:10.22059/ier.2017.64081

[46] Mukhtarova, K., Turekulova, D., Lesbayeva, G., Yesturlieva, A., and Saimagambetova, G. 2018. Analysis and evaluation of environmental management. Journal of Environmental Management and Tourism, 9(1): 167-174. doi:10.14505/jemt.v9.1(25).21

[47] Mulyanto, M., Awatara, I. G. P. D., and Gunardi, A. 2018. Enhancing competence, environmental management 
system, job satisfaction and employee performance. Journal of Environmental Management and Tourism, 9(1): 4045. doi:10.14505/jemt.v9.1(25).06

[48] Nagyová, L. et al. 2016. Economic sustainability of primary agricultural production: the Slovak Republic in the EU context. Journal of Security and Sustainability Issues, 6(2): 259-274. DOI: http://dx.doi.org/10.9770/jssi.2016.6.2(6)

[49] Official website ENGIE. (2017. Available at: http://www.engie.com/en/

[50] Pimonenko, T., Prokopenko, O., and Dado, J. 2017. Net zero house: EU experience in ukrainian conditions. International Journal of Ecological Economics and Statistics, 38(4): 46-57.

[51] Prokopenko, O., Cebula, J., Chayen, S., and Pimonenko, T. 2017. Wind energy in Israel, Poland and Ukraine: Features and opportunities. International Journal of Ecology and Development, 32(1): 98-107.

[52] Simionescu, M., Albu, L. L., Raileanu Szeles, M., and Bilan, Y. 2017. The impact of biofuels utilisation in transport on the sustainable development in the European Union. Technological and Economic Development of Economy, 23(4): 667-686.

[53] Smith, M. 2018. A Real Options Approach to Evaluating Agricultural Investments under Uncertainty: When to Get in and Out of Sugarcane Production. SocioEconomic Challenges, 2(1): 21-34. DOI: 10.21272/sec.2(1).21-34.2018 [54] The green bond market in Europe 2018. 2018. Prepared by the Climate Bonds Initiative. Available at: https://www.climatebonds.net/files/files/The\%20Green\%20Bond\%20Market\%20in\%20Europe.pdf

[55] Thiam Hee Ng, Jacqueline Yujia Tao 2016. Bond financing for renewable energy in Asia, Energy Policy, 95: 509517.

[56] Triodos Bank. Green investment - what does it actually mean? Available at: https://www.triodos.co.uk/en/personal/ethical-investments/green-investments/

[57] Tvaronavičienè, M., Prakapienè, D., Garškaitè-Milvydienè, K., Prakapas, R., and Nawrot, Ł. 2018. Energy efficiency in the long run in the selected European countries. Economics and Sociology, 11(1): 245-254. doi:10.14254/2071-789X.2018/11-1/16

[58] Understanding climate bonds. Climate Bonds Initiative. Available at: https://www.climatebonds.net/resources/understanding

[59] Unlocking the green bond potential in India. Available at: https://archive.nyu.edu/bitstream/2451/42243/2/Unlocking\%20the\%20Green\%20Bond\%20Potential\%20in\%20India.p df

[60] Us, H., and Malyarets, L. 2018. Multi-criteria optimization of the balanced scorecard for the enterprise's activity evaluation: management tool for business-innovations. Marketing and Management of Innovations, (3), 49.

[61] Vasilyeva, T., Lyeonov, S., Adamičková, I., and Bagmet, K. 2018. Institutional quality of social sector: The essence and measurements. Economics and Sociology, 11(2): 248-262. doi:10.14254/2071-789X.2018/11-2/17 [62] Vasylieva, T., Lyeonov, S., Lyulyov, O., and Kyrychenko, K. 2018. Macroeconomic stability and its impact on the economic growth of the country. Montenegrin Journal of Economics, 14(1): 159-170. doi:10.14254/1800$5845 / 2018.14-1.12$

[63] Vasylyeva, T. A., and Pryymenko, S. A. 2014. Environmental economic assessment of energy resources in the context of Ukraine's energy security. Actual Problems of Economics, 160(1): 252-260.

[64] Vasylyeva, T. A., Leonov, S. V., and Lunyakov, O. V. 2014. Countercyclical capital buffer as a macroprudential tool for regulation of the financial sector. Actual Problems of Economics, 158(8): 278-283.

[65] What is a green bond and how does it differ from a regular bond? 2017. World Bank Treasury. Available at: http://treasury.worldbank.org/cmd/htm/Chapter-2-Understanding-Green-Bonds.html

[66] World Development Indicators. DataBank. Available at: http://databank. worldbank.org/data/reports.aspx?source=2\&series=NY.GDP.MKTP.CD\&country=UKR [67] Yao Wang, and Qiang Zhi. 2016. The Role of Green Finance in Environmental Protection: Two Aspects of Market Mechanism and Policies. Energy Procedia, 104: 311-316. 